Available online on 15.05.2020 at http://jddtonline.info
Open Access to Pharmaceutical and Medical Research
unrestricted non-commercial use, provided the original work is properly cited

Open@Access

Research Article

\title{
Acute toxicity of Aristolochia longa L. of aqueous extract in mice
}

\author{
Merouani N. ${ }^{*}$, Belhattab R. ${ }^{2}$ \\ ${ }_{1}^{1}$ Department of Vegetal Biology and Ecology, Faculty of Nature and Life Sciences. Ferhat Abbas University Setif-1. 19000 Setif, Algeria \\ 2 Dept. Biochemistry, Faculty of Nature and Life Sciences. Ferhat Abbas University Setif-1.19000 Setif, Algeria
}

\begin{abstract}
Aristolochia longa L. (Aristolochiaceae) is widely used to treat breast cancer in Algerian traditional medicine. The present study was conducted to investigate the effects of ingestion of aqueous extracts of different parts of the plant on liver and kidney functions in wistar albinos mice. Acute oral toxicity was performed to determine DL50, this toxicity was carried out by the oral administration in single doses of 0 - 12 g/kg for tubers aqueous extracts and $2 \mathrm{~g} / \mathrm{kg}$ and $5 \mathrm{~g} / \mathrm{kg}$ for aerial and fruit aqueous extract respectively. General behavior, adverse effects and mortality were determined for up to 14 days. The animals were sacrificed and biochemical study was done. The acute oral toxicity result revealed that LD50 of the tubers and fruit aqueous extracts was respectively more than $12 \mathrm{~g} / \mathrm{kg}$ and $5 \mathrm{~g} / \mathrm{kg}$, but DL 50 of the aerial aqueous extract was at 5 $\mathrm{g} / \mathrm{kg}$. The result revealed also that liver and kidney function of different groups receiving high doses was affected as ASAT, ALAT, Urea, creatinine was significantly increased as compared to control group. Histological examination showed alterations of the renal parenchyma and the liver which is greater in animals treated with high dose. Thus, caution should be exercised with its usage.
\end{abstract}

Keywords: Acute toxicity, Biochemical parameters, Histological examination Aristolochia longa L.

Article Info: Received 03 March 2020; Review Completed 09 April 2020; Accepted 14 April 2020; Available online 15 May 2020

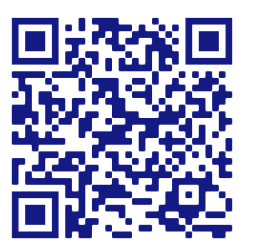

Cite this article as:

Merouani N, Belhattab R, Acute toxicity of Aristolochia longa L. of aqueous extract in mice, Journal of Drug Delivery and Therapeutics. 2020; 10(3):4-10 http://dx.doi.org/10.22270/jddt.v10i3.4055

*Address for Correspondence:

Merouani N., Department of Vegetal Biology and Ecology, Faculty of Nature and Life Sciences. Ferhat Abbas University Setif-1. 19000 Setif, Algeria

\section{INTRODUCTION}

Herbs and herb-derived medicines have played a crucial role in health and disease management for many centuries. Many ancient civilizations show documented evidence for the use of herbs in the treatment of different ailments. The scientific exploitation of herbs used ethnomedicinally for pain relief, wound healing and abolishing fevers has resulted in the identification of a wide range of compounds that have been developed as new therapies for cancer, hypertension, diabetes and as anti-infectives. The earliest report of the toxicity of herbs originated from Galen, a Greek pharmacist and physician who showed that herbs do not contain only medicinally beneficial constituents, but may also be constituted with harmful substances. Toxicity testing can reveal some of the risks that may be associated with use of herbs, therefore avoiding potential harmful effects when used as medicine $\mathbf{1}$.

Various Aristolochia species have been used in herbal medicines since ancient times for treatment of snakebite, festering wounds, and tumors ${ }^{2}$.

Species of Aristolochia are used medicinally in many regions of the world based on ethnopharmacological information

ISSN: 2250-1177 and which also poses some risk based on public health perspective. A systematic assessment of the content of aristolochic acids in the most widely used species is needed to evaluate whether their uses pose a potential health risk ${ }^{2}$.

Aristolochic acids have been frequently found in Aristolochia species. These compounds show toxic effects at the renal level and carcinogenic properties ${ }^{3}$.

Aristolochia longa L. is a common medicinal plant widely distributed in Algeria that belongs to the family Aristolochiaceae. The plant commonly called "Beroustoum in Algeria, Tubers of this plant were used such as astringent, antirheumatic, antitumor, anti-inflammatory and antiseptic 4 , 5,6 .

Toxicity studies have always been considered a vital integral component of drug development bearing in mind that herbal medicines are often used indiscriminately without recourse to the potential side-effects which could vary from being mild, moderate, and severe, to life-threatening7. 8.9.

Hence in the present study the aqueous extracts of the tubers, aerial parts and fruits of Aristolochia longa L. were subjected to acute oral toxicity evaluation in order to assess, 
whether the extracts have any adverse effects or toxic manifestations for long term use. This study therefore was designed to evaluate their toxicity in Albino Wistar mice as toxicity may result from the overdose of these extracts.

\section{MATERIALS AND METHODS}

\section{Plant material}

Aristolochia longa L. plant material was collected in May 2011, $80 \mathrm{~km}$ North of Setif (Algeria). A voucher specimen was deposited in the Nature and Life Sciences Faculty herbarium (University F.A.Setif1, Algeria).

\section{Animal material}

Female Albino Wistar mice were used for acute toxicity. All experimental animals were obtained from Pasteur Institute (Algiers, Algeria). These animals were kept in the animal house of the faculty of Nature and Life Sciences, University of Setif, at a temperature of $20^{\circ} \mathrm{C}$ and a photoperiod cycle of 12 hours light/dark. The animals were housed in plastic cages (divided into 6 groups, 6 mice per cage) and had free access to standard commercial diet and water.

\section{Preparation of plant extract}

The aerial parts (stem and leaves), fruits and tubers were shadow-dried and pulverized to dry powder. For the preparation of water extracts, the plant, $20 \mathrm{~g}$ was extracted with boiling distilled water $(250 \mathrm{ml})$ for $10 \mathrm{~min}$. the extract remained in the warm water for $15 \mathrm{~min}$ and then filtered and concentrated in rotary evaporator $\mathbf{1 0 .}$

\section{Acute toxicity study in mice}

Albino Wistar's females mice with an average weight of $25 \mathrm{~g}$, were divided into six groups of six mice each ( 6 females), including a control group, They were weighed before and after the test, and were deprived of food overnight (12h) with free access to water prior to administration orally of single doses of the tubers aqueous extract successively: 2,4 , $6,8,12 \mathrm{~g} / \mathrm{kg} \mathrm{b} / \mathrm{w}$. And $2 \mathrm{~g} / \mathrm{kg} \mathrm{b} / \mathrm{w}, 5 \mathrm{~g} / \mathrm{kg}$ b/w for areal parts and fruits extracts, the procedure was followed by using OECD (Organization

of Economic Cooperation and Development) guidelines 423 (Acute toxic class method), The control group received only distilled water. The extracts dissolved in distilled water. Animals were gavaged by $1 \mathrm{ml} / 100 \mathrm{~g} \mathrm{~b} / \mathrm{w}$. The general behavior of mice and clinical symptoms of toxicity (morbidity) were registered. Animals were observed individually every hour during the first day (with special attention given during the first 4 hours), and then daily thereafter, for a total of 14 days.

\section{Measurement of biochemical parameters in blood}

After 14 days, blood samples are taken after dissection of mice for biochemical analysis, cholesterol (CHOL); glucose
(GLU); triglycerides (TG); aspartate aminotransferase (AST); alanine aminotransferase (ALT); Urea; creatinine (CREA); alkaline phosphatase (ALP).

\section{Histopathological assessment}

At the end of the experiment, mice were sacrificed and their liver and kidneys were carefully dissected out, and rinsed in $0.9 \% \mathrm{NaCl}$, then fixed in the formol (10\%), sectioned $5 \mu \mathrm{m}$ thickness, and embedded in paraffin and stained with hematoxylin and eosin $\mathbf{1 1}$ and examined with a light microscope. The histopathology slides were viewed at various magnifications $(\times 40$ and $\times 100)$ to detect pathological lesions.

\section{Statistical analysis}

The results are expressed as the mean value \pm standard deviation. One-way analysis of variance followed by the Tukey test was performed to assess differences between groups. Differences were considered significant at $\mathrm{p}<0.05$. Statistical analyses were performed with the aid of the software GraphPad Prism 5®.

\section{RESULTS AND DISCUSSION}

Acute toxicity of tubers, aerial parts and fruits aqueous extracts of $A$. longa in mice

No abnormality in the general behaviour of the test animals either in the short term or long term was observed. Treated animals exhibited normal behaviour as that of control group. No death was observed in any of the group and all the animals lived up to 14 days, except in the treated group with aerial parts aqueous extracts mortality was observed at the dose of $5 \mathrm{~g} / \mathrm{kg}$.

Effect of Aristolochia longa L. aqueous extract on mice body weight

There was no body weight loss during the observation period. But all the animals exhibited a gain in body weight (Fig. 01). The weight gain (Fig. 01) was estimated for the control at $16.49 \%$, for the groups treated at $5.95 \%, 4.49 \%$, $4.61,3.35 \%$ and $7.48 \%$ for the respective doses of the tubers aqueous extract D1, D2, D3, D4, and D5. Weight gain for aerial parts aqueous extracts (AAE D2 $=2 \mathrm{~g} / \mathrm{kg}$,) is $16,63 \%$, and for the fruits aqueous extract (FAE) it is $4.78 \%$ and $1.23 \%$ (respective doses D2 = $2 \mathrm{~g} / \mathrm{kg}$ and D5 = 5g / kg) (Fig. 2). Since changes in body weight have been used as an indicator of adverse effects of drugs and chemicals.

The obtained results (Fig. 01and Fig. 02) also suggest that the aqueous extracts of Aristolochia longa L. did not affect the increase in body weight as well as water and food intake, indicative of nontoxic nature of the plant. 


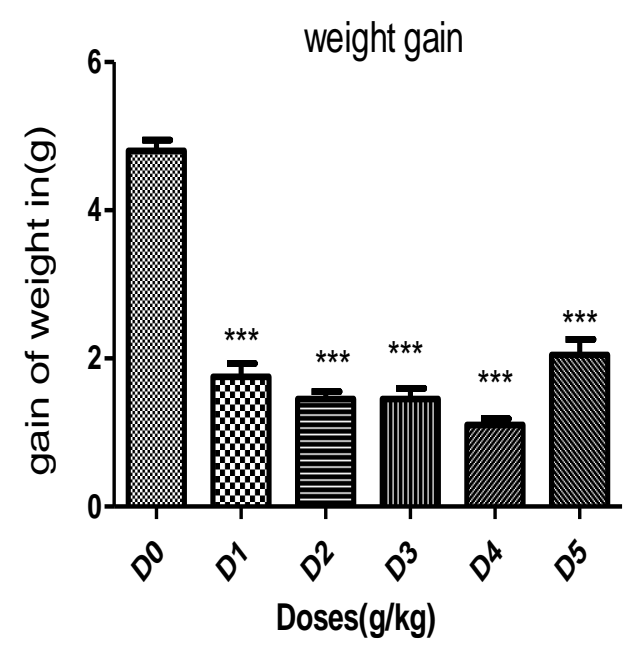

Fig.01: Alterations in the body weight of female mice after acute oral treatment with tubers aqueous extract of Aristolochia longa $\mathrm{L}$. The values are expressed as mean \pm SD ( $=6 /$ group). Doses : D0, control ; D1 (2 g/kg), D2 (4g/kg), D3 $(6 \mathrm{~g} / \mathrm{kg})$. ; D4 (8g/kg), D5 (12g/kg).

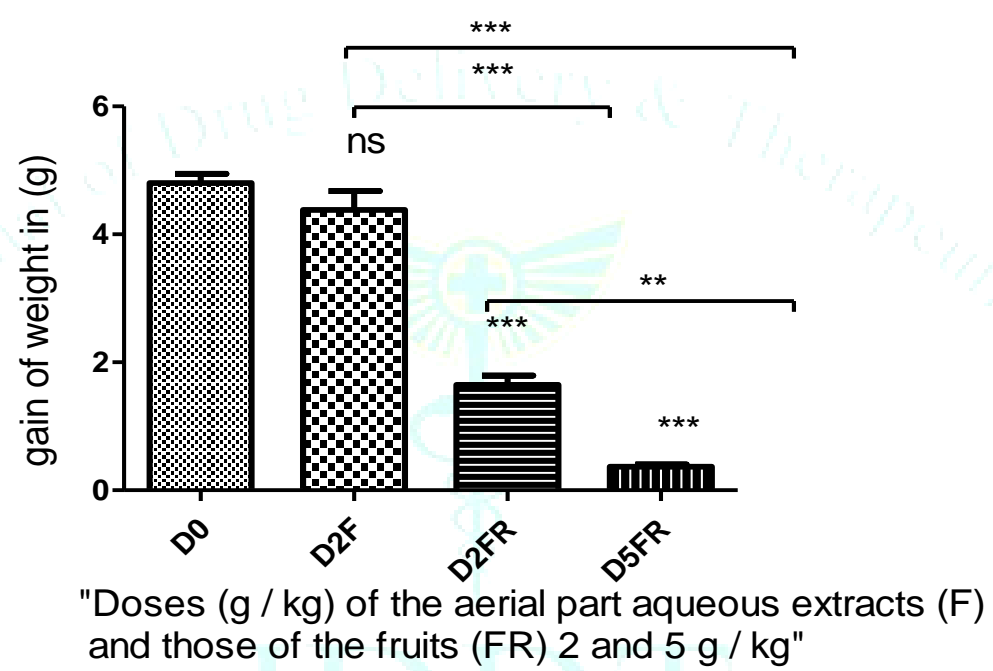

Fig.02: Alterations in the body weight of female mice after acute oral treatment with aerial part aqueous extract (F) those of the fruits(FR) of Aristolochia longa $\mathrm{L}$. The values are expressed as mean \pm SD ( $\mathrm{n}=6 /$ group). Doses: D0, control; D2F, D2FR (2 g/kg), D5FR (5g/kg).

\section{Effect of aqueous extract on biochemical parameters}

Clinical biochemistry and hematological data holds significant role in determining the toxicity induced by drugs. Transaminases (SGOT (AST) and SGPT (ALT)) are good indicators of liver function and biomarkers to predict the possible toxicity of drugs. Any elevation pertaining to these enzymes indicate their outflow into the blood stream due to damage in liver parenchymal cells $\mathbf{1 2}$.

However, biochemical parameters related to hepatic functions such as ALT, AST and ALP significantly decreased. Reduction in the levels of these enzymes indicates that the extract did not, have any toxic effects on both liver and heart.
In our study, on administration of tubers aqueous extract there is no significant $(\mathrm{p}>0.05)$ change in glycemia, cholesterol and alkaline phosphatase (ALP) values, however, there was a significant rise in serum AST, ALT levels compared to respective control values in mice treated with high doses of this extract $(12 \mathrm{~g} / \mathrm{kg})$, due to hepatic cell necrosis which leads to membrane fragility and leakage of these enzymes in circulation, and it also caused increase in the renal function tests (creatinine) (Table 01). As shown in Table 02, the same results are obtained for the extract of the aerial part and those of fruits at the dose of $(5 \mathrm{~g} / \mathrm{kg})$, so Biochemical analyzes show that biochemical factors are particularly disturbed at high doses. 
Table 01. Effect of tubers aqueous extract of Aristolochia longa L. (with doses D0 (0 g / kg), D1 (2g / kg), D2 (4g / kg) ), D3 (6g / kg), D4 (8g / kg), D5 (12g / kg).) in per os on biochemical parameters in female Wistar mice treated for 14 days

\begin{tabular}{|c|c|c|c|c|c|c|}
\hline \multirow{2}{*}{ Biochemical tests } & \multicolumn{6}{|c|}{ Dose } \\
\hline & $\mathbf{D}_{0}$ & $\mathbf{D}_{1}$ & $\mathbf{D}_{2}$ & $\mathbf{D}_{3}$ & $\mathbf{D}_{4}$ & $\mathbf{D}_{5}$ \\
\hline ALT $\quad(U I / l)$ & $44 \pm 5,83$ & $56,5 \pm 6,92 \mathrm{~ns}$ & $36,67 \pm 4,71^{\mathrm{ns}}$ & $46 \pm 6,95^{\mathrm{ns}}$ & $47 \pm 6^{\mathrm{ns}}$ & $72 \pm 11,19^{* * *}$ \\
\hline AST (UI/l) & $166,5 \pm 21,15$ & $180,5 \pm 29,55$ & $131,5 \pm 22,63 \mathrm{~ns}$ & $228,5 \pm 36,13^{*}$ & $175,5 \pm 13,77 \mathrm{~ns}$ & $323,5 \pm 44,21^{\text {*** }}$ \\
\hline ALP (UI/l) & $154,5 \pm 12.32$ & ns & $152 \pm 13,45 \mathrm{~ns}$ & $144 \pm 12,02 \mathrm{~ns}$ & $140 \pm 21,34 \mathrm{~ns}$ & $177 \pm 26,89 \mathrm{~ns}$ \\
\hline CREATE (mg/l) & $5,05 \pm 0.40$ & $124 \pm 16,21^{\mathrm{ns}}$ & $6,2 \pm 0,64 \mathrm{~ns}$ & $5,65 \pm 0,23 \mathrm{~ns}$ & $5,75 \pm 0,75^{\mathrm{ns}}$ & $6,4 \pm 0,65^{*}$ \\
\hline Urea (mg/l) & $0,385 \pm 0,029$ & $6 \pm 1,11 \mathrm{~ns}$ & $0,3 \pm 0,05^{* *}$ & $0,3 \pm 0,02^{* *}$ & $0,285 \pm 0,02^{* * *}$ & $0,235 \pm 0,03^{* * *}$ \\
\hline CHOLESTEROL (g/l) & $1,052 \pm 0,08$ & $0,35 \pm 0,03$ ns & $1,18 \pm 0,165^{\mathrm{ns}}$ & $1,29 \pm 0,06 \mathrm{~ns}$ & $1,19 \pm 0,16$ ns & $1,115 \pm 0,17 \mathrm{~ns}$ \\
\hline TRIGLYCERIDE(g/l) & $1,28 \pm 0,19$ & $1,18 \pm 0,117 \mathrm{~ns}$ & $1,65 \pm 0,27 \mathrm{~ns}$ & $1,6 \pm 0,22 \mathrm{~ns}$ & $1,55 \pm 0,24 \mathrm{~ns}$ & $1,25 \pm 0,17$ ns \\
\hline GLYCEMIE (g/l) & $1,46 \pm 0,15$ & $\begin{array}{l}1,15 \pm 0,18 \text { ns } \\
1,35 \pm 0,15 \text { ns }\end{array}$ & $1,515 \pm 0,24 \mathrm{~ns}$ & $1,51 \pm 0,17 \mathrm{~ns}$ & $1,58 \pm 0,22 \mathrm{~ns}$ & $1,51 \pm 0,12 \mathrm{~ns}$ \\
\hline
\end{tabular}

Table 02. Effect of fruits aqueous extract (FR) and areal aqueous extract (F) of Aristolochia longa L. (with doses D0 (0 $\mathrm{g} / \mathrm{kg})$, D1 (2g/kg) D2FR, D2 (2g/kg) D2F, D5 (5g/kg) D5FR in per os on biochemical parameters in female Wistar mice treated for 14 days

\begin{tabular}{|l|l|l|l|l|}
\hline \multirow{2}{*}{ Biochemical tests } & \multicolumn{4}{|c|}{ Dose } \\
\cline { 2 - 5 } & $\mathbf{D}_{\mathbf{0}}$ & $\begin{array}{l}\text { D } \\
\text { D2FR }\end{array}$ & $\begin{array}{l}\mathbf{D}_{2} \\
\text { D2F }\end{array}$ & $\begin{array}{l}\text { D }_{3} \\
\text { D5FR }\end{array}$ \\
\hline ALT (UI/l) & $44 \pm 5,83$ & $42,5 \pm 2,5^{\mathrm{ns}}$ & $45,5 \pm 6,5 \mathrm{~ns}$ & $66,5 \pm 8,5^{* *}$ \\
AST (UI/l) & $166,5 \pm 21,15$ & $143,5 \pm 5,5^{\mathrm{ns}}$ & $203,7 \pm 32,72^{\mathrm{ns}}$ & $168 \pm 2^{\mathrm{ns}}$ \\
ALP (UI/l) & $154,5 \pm 12.32$ & $154,5 \pm 3,5^{\mathrm{ns}}$ & $166,5 \pm 11,5^{\mathrm{ns}}$ & $186 \pm 8^{* *}$ \\
CREATE (mg/l) & $5,05 \pm 0.40$ & $6,25 \pm 0,15^{*}$ & $6,26 \pm 0,23^{* *}$ & $7,1 \pm 0,72^{* * *}$ \\
UREE (mg/l) & $0,385 \pm 0,029$ & $0,345 \pm 0,04 \mathrm{~ns}$ & $0,355 \pm 0,005^{\mathrm{ns}}$ & $0,36 \pm 0,03^{\mathrm{ns}}$ \\
CHOLESTEROL (g/l) & $1,052 \pm 0,08$ & $1,15 \pm 0,05^{\mathrm{ns}}$ & $0,915 \pm 0,04^{\mathrm{ns}}$ & $1,14 \pm 0,05^{\mathrm{ns}}$ \\
TRIGLYCERIDE(g/l) & $1,283 \pm 0,19$ & $1,35 \pm 0,15^{\mathrm{ns}}$ & $1,55 \pm 0,05^{\mathrm{ns}}$ & $1,23 \pm 0,15^{\mathrm{ns}}$ \\
GLYCEMIE (g/l) & $1,46 \pm 0,15$ & $1,825 \pm 0,025^{\mathrm{ns}}$ & $2,03 \pm 0,32^{* *}$ & $1,88 \pm 0,07^{*}$ \\
\hline
\end{tabular}

Values represent the mean \pm S.D. ( $\mathrm{n}=6 /$ group). ns: non significance. $*(\mathrm{P} \leq 0.05),{ }^{* *}(\mathrm{P} \leq 0.01),{ }^{* * *}(\mathrm{P} \leq 0.001)$

Effect of Aristolochia longa L. aqueous extract on mice organs weight

About the mice treated with the tubers aqueous extract of the plant, significant elevations of the values of the relative mass of the kidneys at the high doses D4 (8g / kg), D5 (12g / $\mathrm{kg}$ ) were observed compared to the control kidney. As for the relative mass of the liver, the values appear normal compared to the control liver (Figure 3). Similarly, the aqueous extracts of the aerial part and those of the fruits were observed that they cause an increase in the relative kidney weight at the high doses (5g / kg) (Fig.4). Generally, the change in internal organ weight is a toxicity index after exposure to a toxic substance $\mathbf{1 3}, \mathbf{1 4}$. relative liver weight

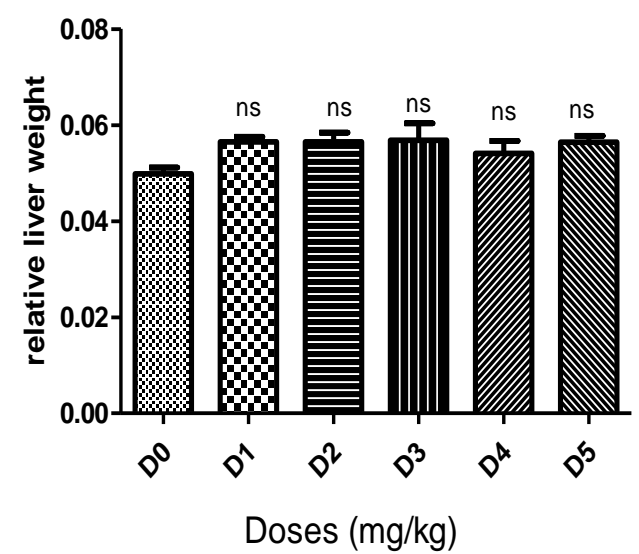

relative kidneys weight

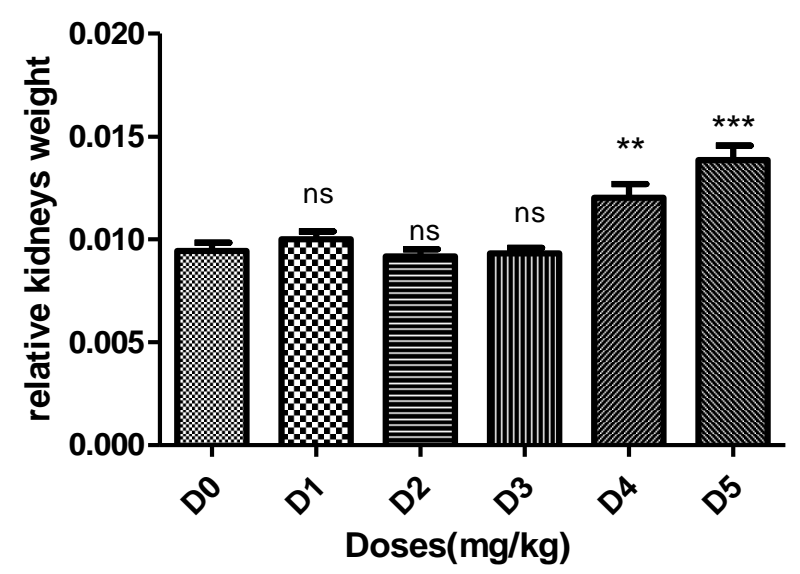

Fig.03: The effect of tubers aqueous extract of Aristolochia longa $\mathrm{L}$ administered orally at different doses on the weight of mice organs Doses : D0, control; D1 (2 g/kg), D2 (4g/kg), D3 (6/kg). ; D4 (8g/kg), D5 (12g/kg). 

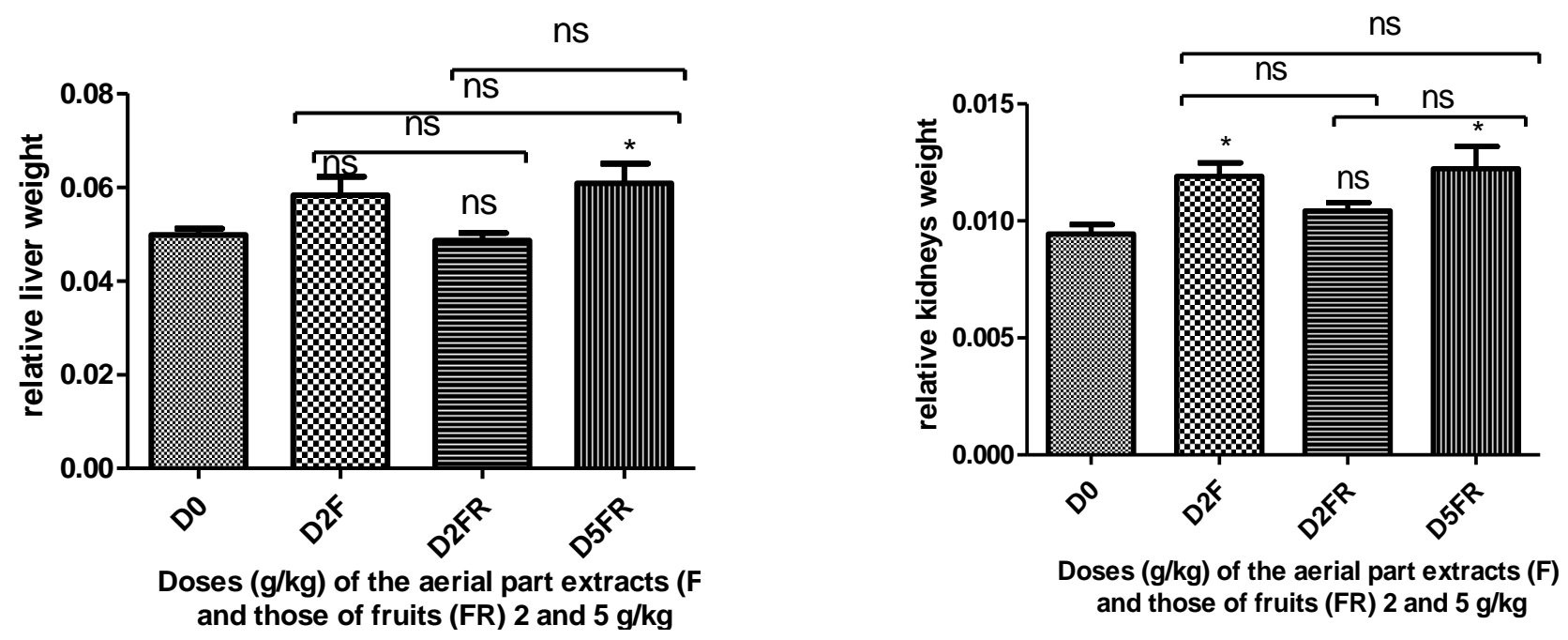

Fig.04: The effect of the aerial part extracts (F) and those of fruits (FR) of Aristolochia longa L administered orally at different doses on the weight of mice organs Doses : D0, control; D2F,D2FR (2 g/kg), D5FR (5g/kg).

According to 15 the biochemical results (disturbance of biochemical parameters) are confirmed by the results of the histological examination. So histological study appears to be a very sensitive parameter and is crucial in determining cellular changes that may occur in target organs, such as the liver $\mathbf{1 6}^{16}$

Histological examination of the liver and kidneys of treated mice showed that the cellular (lobular and tubular) architecture of the parenchyma is well preserved compared to control mice., except in the high doses $(12 \mathrm{~g} / \mathrm{kg}, 5 \mathrm{~g} / \mathrm{kg}$ respectively for the tubers aqueous extracts and the aqueous extracts of the aerial part and those of fruits, we noted the presence of a congestion, necrosis, glomerular atrophy, dilated sinusoids and autolysis of the renal cells (Figs 5 and 6). In this study, we have shown the damages were more pronounced particularly in renal tissue, this is also confirmed by the study of 15,17 .
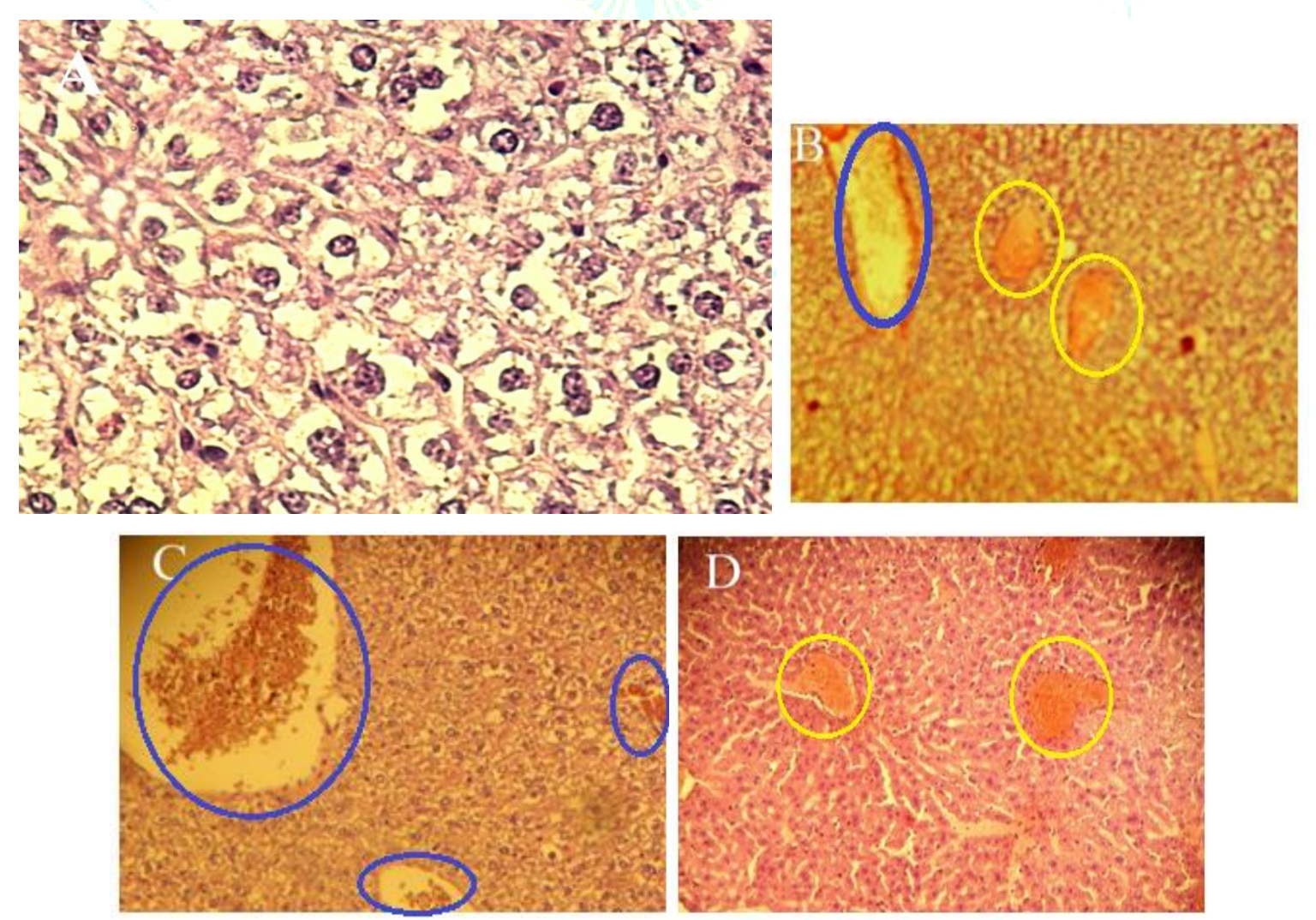

Fig.05:Histopathological changes in the liver's mice treated with Aristolochia longa L. aqueous extract orally in mice.

(A) Control mice $(0 \mathrm{~g} / \mathrm{kg}$ ) normal mice liver showing normal hepatic architecture, (B) treated with $12 \mathrm{~g} / \mathrm{kg}$ (tubers aqueous extract), (C) treated with $5 \mathrm{~g} / \mathrm{kg}$ (fruit aqueous extract) , (D) treated with $5 \mathrm{~g} / \mathrm{kg}$ (areal parts aqueous extract). Congestion (blue circle), hepatocellular necrosis (yellow circle). Magnifications $(\times 100)$ 

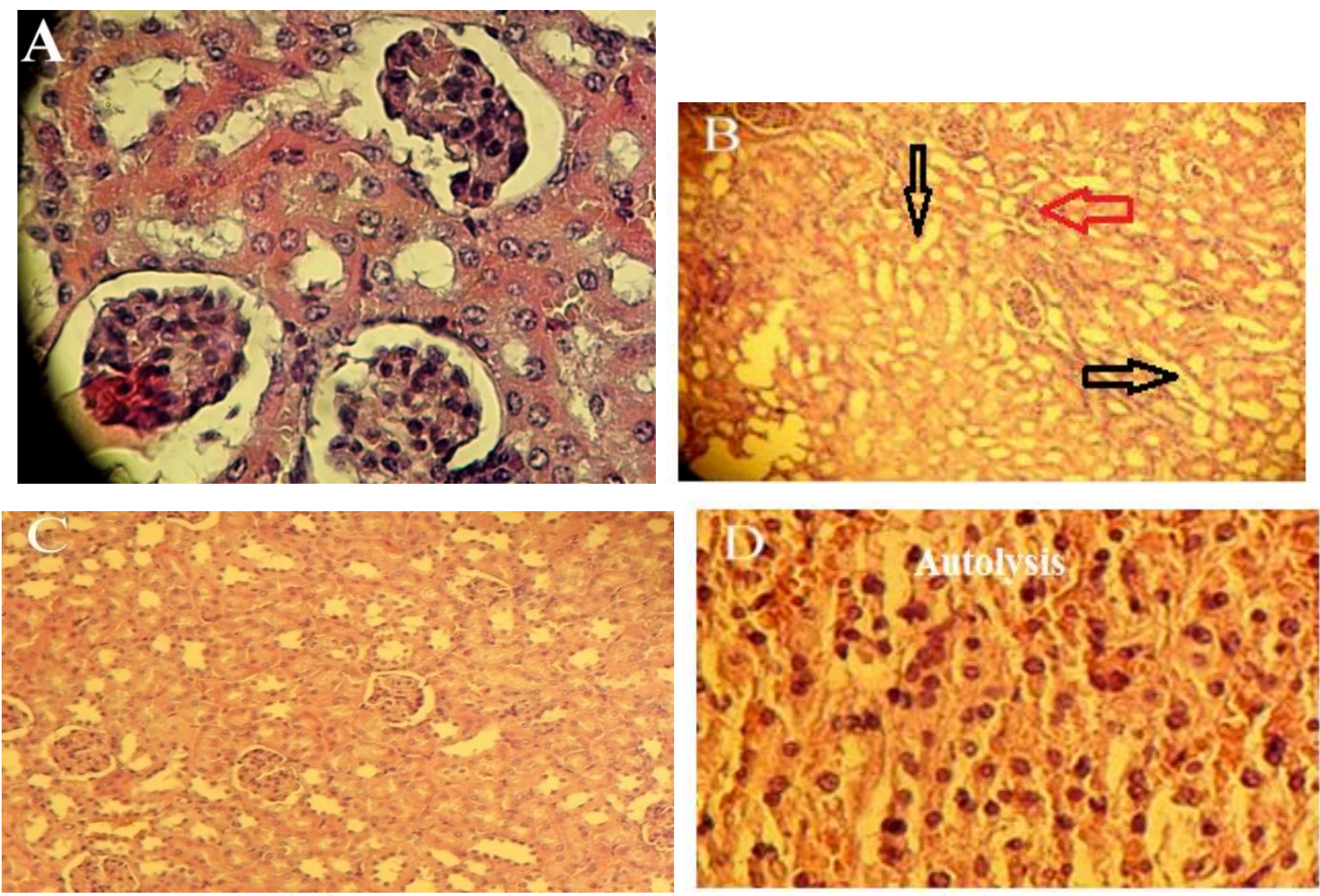

Fig.06:Histopathological changes in the Kidney of mice treated with Aristolochia longa L. aqueous extract orally in mice. (A) Control mice ( $0 \mathrm{~g} / \mathrm{kg}$ ), (normal parenchyma), (B) treated with $12 \mathrm{~g} / \mathrm{kg}$ (tubers aqueous extract), (C) treated with $5 \mathrm{~g} / \mathrm{kg}$ (fruit aqueous extract) , (D) treated with $5 \mathrm{~g} / \mathrm{kg}$ (areal parts aqueous extract). Glomerular atrophy (red arrows), dilated sinusoids (black arrow), Autolysis (altered tissue architecture). Magnifications $(\times 100)$

Results of many sub chronic toxicity tests of various plant extracts showed that the major organs usually affected are the liver and kidneys. Hepatotoxic and nephrotoxic effects are mostly to be expected, as the liver acts as the main detoxifying organ for chemical substances, while the kidney is a principal route of excretion for many chemical substances in their active and/or inactive forms $\mathbf{1 .}$

Determination of acute oral toxicity is usually an initial screening step in the assessment and evaluation of the toxic characteristics of all compounds, Acute toxicity is involved in estimation of LD50 (the dose which has proved to be lethal (causing death) to $50 \%$ of the tested group of animals) $\mathbf{1 8}$.

The results of the acute toxicity study indicated that tubers aqueous extract via oral route with the doses from 2 to 12 $\mathrm{g} / \mathrm{kg}$ body weight did not produce any sign of toxicity or death in mice after 14 days of observation. According to the classification of Hodge and Sterner 19 Chemical substances with a LD50 between 5000 and $15000 \mathrm{mg} / \mathrm{kg}$ body weight determined after single oral doses in mice is considered as practically non-toxic in humans. Therefore, the tubers aqueous extract of Aristolochia longa L. could be considered practically non-toxic with respective LD50 greater than $12 \mathrm{~g}$ / $\mathrm{kg}$. As for the fruit aqueous extract we have obtained the same results regarding signs of toxicity as the previous extract at different doses ( 2 and $5 \mathrm{~g} / \mathrm{kg}$ body weight),according to the annex $2 \mathrm{~d}$ for OECD guidelines 423 , the LD50 has been selected greater than $5 \mathrm{~g} / \mathrm{kg}$, so this extract has been classified as non-toxic in humans (regarding Hodge and Sterner classification), The results of the acute toxicity assessment indicate safety in the use of the plant as the test animals survived the $5000 \mathrm{mg} / \mathrm{kg}$ dosing because an LD50 value greater than $5 \mathrm{~g} / \mathrm{kg}$ is of no practical interest 20 . In addition to the aqueous extract of the aerial part, the $2 \mathrm{~g} /$ $\mathrm{kg}$ dose is not harmful, whereas the $5 \mathrm{~g} / \mathrm{kg}$ dose caused the death of the mice after $24 \mathrm{~h}$ of the administration of this extract, so the LD50 is at $5 \mathrm{~g} / \mathrm{kg}$ according to the annex $2 \mathrm{~d}$ for OECD guidelines 423 , as a consequence this extract could be considered practically low-toxic (Hodge and Sterner classification).

We obtained similar results in comparison with the study of 21 where, a single oral administration of aqueous extract of $A$. longa at $2.5 \mathrm{~g} / \mathrm{kg}$ body weight did not produce any visible toxic effects compared with the control, but in Sub-chronic toxicity Serum levels of ALAT and ASAT and concentration of 'creatinine' were markedly and significantly increased in mice treated by $2.5 \mathrm{~g} / \mathrm{kg}$ of aqueous extract of $A$. longa, Therefore, $A$. longa $\mathrm{L}$. induced serious kidney and liver injury. Our results were confirmed also by $\mathbf{1 7}$ who reported that in the acute toxicity study, in which doses up to $5000 \mathrm{mg} / \mathrm{kg}$ (body weight) were administered, the $A$. longa aqueous root extract was found to be safe. As well ${ }^{15}$ study's of the aqueous extract of the roots acute toxicity in male and female mice, administered orally, has checked its safety to a singles doses of $1 \mathrm{~g} / \mathrm{kg}$ to $5 \mathrm{~g} / \mathrm{kg}$, and the extract tested is considered nontoxic or very little to a single dose. According to 22 , there seems to be no cases of acute human poisoning by species of the genus Aristolochia and animal poisoning are infrequent. However, these plants are particularly dangerous when ingested over a long period, especially because they cause a nephropathy called "Chinese herbal nephropathy" "AA nephropathy" 15. 23 was observed in his study of acute toxicity of alcoholic extract of the aerial parts of Aristolochia indica L. a mortality in the groups of mice treated with the dose $10 \mathrm{~g} / \mathrm{kg}$ body weight, and he concluded that the dose of A. indica L.(1500mg/g body weight) significantly increased blood levels of AST, ALT, total proteins indicating liver 
toxicity and increased blood urea nitrogen and creatinine and significantly decreased level of uric acid as compared to group control showing that kidney function and liver were affected.

The plant contain Aristolochic acid has many medicinal properties in various disease condition 24,25. Aristolochic acids have been frequently found in Aristolochia species, despite their virtues. These compounds show toxic effects at the renal level and carcinogenic properties $\mathbf{0 3}$.

Consumption of many plants of the genus Aristolochia can lead to progressive nephropathy and urothelial cancer in humans 26.

\section{CONCLUSION}

The biochemical results and the results of the histological examination of the kidneys and liver obtained in this study, suggest that the administration of extracts of the plant Aristolochia longa L. at high doses affects the tissues of the kidneys and livers. Where the deleterious effects are more severe on renal functions of mice. These observations suggest that this plant should be used with caution in order to avoid renal toxicities.

\section{REFERENCES}

[01] Ifeoma O., Oluwakanyinsola S. Screening of Herbal Medicines for Potential Toxicities (Chapter 4), 63 - 88 IN : New Insights into toxicity and drug Testing. Edition Sivakumar Gowder, Publisher: Intech, 2013. 252 p.

[02] Latha S., Selvamani P., Dhivya P. S., Benaseer Begam, R. A review on pharmacological activities of Aristolochia species. European journal of biomedical and pharmaceutical sciences, 2015; 2(5): 160-167.

[03] Pacheco A.,G., de Oliveira P., M., Piló-Veloso D., Alcântara A.F. C. 13C-NMR Data of Diterpenes Isolated from Aristolochia Species. Molecules, 2009; 14: 1245-1262.

[04] Djeridane A., Yousfi M., Nadjemi B., Maamri S., Djireb F., Stocker, P. Phenolic extracts from various Algerian plants as strong inhibitors of porcine liver carboxylesterase. Journal of Enzyme Inhibition and Medicinal Chemistry , 2006;21(6) : 719-726.

[05] Cherif H.S., Saidi F., Boutoumi H., Rouibi A., Chaouia C. Identificatioet caractérisation de quelques composés chimiques chez Aristolochia longa L. Agricultura- Științã și practicã , 2009;3( 4) :76-82.

[06] Benarba B., Meddah B. Ethnobotanical study, antifungal activity, phytochemical screening and total phenolic content of Algerian Aristolochia longa. J Intercult Ethnopharmacol, 2014; 3(4):150154.

[07] World Health Organization. Principles for the Safety Assessment of Food Additives and Contaminants in Food, 1987; IPCS Environmental Health Criteria70. Geneva: World Health Organization

[08] World Health Organization. General Guidelines for Methodologies on Research and Evaluation of Traditional Medicine, 2000; Geneva: WHO Press, World Health Organization.

[09] Akindele A.j., Adeneye A. A., Salau O. S., Sofidiya M. O., Benebo A. S. Dose and time-dependentsub-chronic toxicity study of hydroethanolic leaf extract of Flabellaria paniculata Cav.(Malpighiaceae) inrodents. Ethnopharmacology, 2014; 5(78):1-11.

[10] Belhattab R., Larous, L., Kalantzakis G., Boskou D., Exarchou V. Antifungal properties of Origanum glandulosum Desf. extracts. Food, Agriculture \& Environment , 2004;2 (1):69-73.
[11] Bensalem-bendjelloul M. Techniques histologiques théorie et pratique. Algérie: Office des publications universitaires; 1998.

[12] Amala Hazel A.M, Pattarayan R., Banumathy V. Acute and subacute (28-days) oral toxicity studies of Eraippu noi chooranam. International Journal of Advanced Research in Biological Sciences, 2016; 3 (6): 106-112.

[13] Raza M., Al-Shabanah O.A., El-Hadiyah T.M., Al-Majed A.A. Effect of prolonged vigabatrin treatment on hematological and biochemical parameters in plasma, liver and kidney of Swiss albino mice. Scientia Pharmaceutica, 2002; 70: 135-145.

[14] Teo S., Stirling D., Thomas S., Hoberman A., Kiorpes A., Khetani V. A 90-day oral gavage toxicity study of d-methylphenidate and d,l-methylphenidate in Sprague-Dawley rats.Toxicology, 2002; 179: 183-196.

[15] Cherif H.S., Saidi F., Guedioura A. Toxicological evaluation of Aristolochia longa L.extract in mice. Indian Journal of Applied Research, 2014; 5: 26-30.

[16] Abdel-Warith A. A., Younis E. M., Al-Asgah N. A., Wahbi O. M. Effect of zinc toxicity on liver histology of Nile tilapia,Oreochromis niloticus. Scientific Research and Essays, 2011; 6(17):3760-3769.

[17] Benarba B., ambroise G., Aoues A., Meddah B., Vazquez A. Aristolochia longa aqueous extract triggers the mitochondrial pathway of apoptosis in BL41 Burkitt's lymphoma cells. International Journal of Green Pharmacy, 2012; 6: 45-9.

[18] Akhila S. J., Deepa S., Alwar M.C. Acute toxicity studies and determination of median lethal dose. Current Science, 2007, 93(7):917 - 920.

[19] Ouedraogo Y., Nacoulma O., Guissou I.P., Guede Guina F. Evaluation in vivo et in vitro de la toxicité des extraits aqueux d'ecorces de tige et de racines de Mitragyna inermis(Willd).0.Ktz (Rubiaceae). Pharm. Méd. Trad. Afr, 2001; 11:13-29.

[20] Adewoyin F. B., Omisore N. O., Odaibo A. B., Adewunmi C. O., Iwalewa E. O. In vivo Antiplasmodial Activity and Haematological Parameters of the Methanolic Extract of Clerodendrum polycephalum Baker Leaves on Plasmodium berghei berghei in Mice. European Journal of Medicinal Plants, 2016; 12 (1): 1-8.

[21] Benzakour G., Benkirane N., Amrani M., Oudghiri M. Immunostimulatory potential of Aristolochia longa L.induced toxicity on liver, intestine and kidney in mice. Journal of Toxicology and Environmental Health Sciences, 2011; 3(8): 214222.

[22] Bruneton J. Plantes toxiques: végétaux dangereux pour l'homme et les animaux. Edition Tec \& Doc. Lavoisier; 2005. 618 p.

[23] Mridula, M., Shikha, G., Abid, M.,Ghosh, AK. Toxicity study of alcoholic extract of the aerial parts of Aristolochia Indica L. International journal of Research in Ayurveda et pharmacy, 2011; 2(5):1560-1562.

[24] Angalaparameswari S., Mohamed Saleem T.S., Alagusundaram M., Ramkanth S., Thiruvengadarajan V.S., Gnanaprakash K., Madhusudhana Chetty C., Prathees, G. Anti-microbial Activity of Aristolochic Acid from Root of Aristolochia bracteata Retz. World Academy of Science, Engineering and Technology, 2011; 57: 1017-1020.

[25] Thirumal M., Vadivelan R., Kishore G., Brahmaji V.S. Aristolochia bracteolata: An Overview on Pharmacognostical, Phytochemical and Pharmacological Properties. Critical review in pharmaceutical sciences, 2012; 2(1):70-82.

[26] Nortier J., Pozdzik A., Roumeguere T., Jean-Louis Vanherweghem J-L. Néphropathie aux acides aristolochiques « néphropathie aux herbes chinoises »). Néphrologie \& Thérapeutique, 2015 ;

http://dx.doi.org/10.1016/j.nephro.2015.10.001. 